SHORT COMMUNICATION

\title{
Digestive and regenerative cells in the midgut of haploid and diploid males of the stingless bee Melipona quadrifasciata anthidioides (Hymenoptera: Apidae)
}

\author{
Kenner M. Fernandes ${ }^{1}$, Gustavo F. Martins ${ }^{1,2}$, José E. Serrão ${ }^{1} \&$ Clóvis A. Neves ${ }^{1}$ \\ ${ }^{1}$ Departamento de Biologia Geral, Universidade Federal de Viçosa. 36570-000Viçosa, MG, Brazil. \\ 2 Corresponding author. E-mail: gmartins@ufv.br
}

\begin{abstract}
In eusocial bees, workers and queens are diploid (2n), whereas males are haploid (n). However, in some species, including the stingless bee Melipona quadrifasciata anthidioides Lepeletier, 1836, 2n males arise from fertilized eggs resulting from the crossing between a queen and her brother. In the present study, we provide a comparative analysis of the digestive and regenerative cells in $\mathrm{n}$ and $2 \mathrm{n}$ pupae and adult males of M. quadrifasciata anthidioides. In $\mathrm{n}$ and $2 \mathrm{n}$ pupae and adult males, the number of regenerative cells/nest was similar. In $\mathrm{n}$ and $2 \mathrm{n}$ pupae, the mean number of digestive cells/midgut area was $2076 \pm 0.60$, whereas in adults it was $1234 \pm 1.42$ digestive cells/midgut area. The nuclear area of the digestive cells was also similar in both $\mathrm{n}$ and $2 \mathrm{n}$ adult males $\left(\sim 154 \mu \mathrm{m}^{2}\right)$ and smaller in pupae $(\sim 91$ $\left.\mu \mathrm{m}^{2}\right)$; this variation might be a result of DNA amplification in digestive cells during bee development. The results from our current study provide further understanding of the morphological and physiological aspects of the digestive tract of bees and show that the ploidy difference between $\mathrm{n}$ and $2 \mathrm{n}$ male stages does not affect the number of digestive and regenerative cells in the midgut of $M$. quadrifasciata anthidioides.
\end{abstract}

KEY WORDS. Digestive system; drones; eusocial insect; morphology.

The midgut of bees is an enlarged tubular-shaped organ that is formed by a single epithelium comprising three different cell types: digestive, which are the most abundant, regenerative and endocrine cells (Cruz-Landim \& Mello 1970, Neves et al. 2003). Digestive cells have a role in synthesizing digestive enzymes, and in absorbing nutrients (reviewed by Terra 1990). Small undifferentiated regenerative cells are located among the digestive cells and occur as isolated cells or in clusters; such cells can differentiate into digestive cells during metamorphosis and, in several species of insects, also throughout their lifespan (BiLLingSLey \& LeHANe 1996).

In eusocial bees, individuals are divided into well-defined castes. The queen constitutes the reproductive caste; workers are responsible for foraging and for maintaining the colony; and males (drones) are haploid and fertilize the queen (Michener 1974). Haploid (n) males develop by arrhenotokous parthenogenesis from unfertilized eggs, whereas diploid (2n) males originate from fertilized eggs, which result from the crossing between virgin queens and their brothers (Соо 1993). In the case of the stingless bee Melipona quadrifasciata anthidioides Lepeletier, 1836 , the offspring are formed by workers and $2 \mathrm{n}$ males at $1: 1$ ratio (CAMARgo 1979). These $2 \mathrm{n}$ males have the same phenotype as $\mathrm{n}$ males, but their lifespan and feasibility are reduced in comparison to n males (Rothenbuhler et al. 1968, CAMARgo 1982).

It has previously been reported that, in bees, the morphology of the midgut and its cellular composition differ depending on the species, caste or gut region (RAEs et al. 1994, Serrão \& Cruz-Landim 1996, 2000, Cruz-Landim 1999, França et. al. 2006). FERNANDES et al. (2010) showed that there are morphological differences between digestive cells of different castes of M. quadrifasciata anthidioides. For instance, in M. quadrifasciata anthidioides, queens and nurse workers, the nuclei of digestive cells are bigger than the nuclei found in the digestive cells of forager workers. However, little was known about the differences between the midgut cell morphology of $n$ versus $2 \mathrm{n}$ males. Here, we report on the first comparative study of the midgut of $\mathrm{n}$ and $2 \mathrm{n}$ males of the stingless bee M. quadrifasciata anthidioides, examining the number and the area of nuclei of digestive and regenerative cells of both pupae and adults. Such a comparative approach can contribute to understanding the morphological and physiological aspects of the digestive tract of bees.

In total, 16 black-eyed pupae and 14, 10-day-old adults of both $\mathrm{n}$ and $2 \mathrm{n}$ males of M. quadrifasciata anthidioides were obtained from n- and $2 \mathrm{n}$ male-producing nests kept in the api- 
ary at the Universidade Federal de Viçosa, Minas Gerais, Brazil. Brood chambers containing pupae were removed from the hives and transferred to Petri dishes. After emergence, the adults were fed honey:distilled water (1:1) until dissection. Samples were maintained at $28 \pm 1^{\circ} \mathrm{C}, 45 \pm 5 \%$ relative humidity and 24 -h scotophase. The haploidy and diploidy of the adults were confirmed following the dissection of the males and the visual inspection of their testes under a stereomicroscope. It is known that $2 \mathrm{n}$ males have smaller testes compared with those of $\mathrm{n}$ males (Woyke \& SKowroner 1974, Duchateau \& MariëN 1995).

Insects were anesthetized at $4^{\circ} \mathrm{C}$ and dissected in insect saline solution $\left(0.1 \mathrm{M} \mathrm{NaCl}, 20 \mathrm{mM} \mathrm{KH}_{2} \mathrm{PO}_{4}\right.$ and $20 \mathrm{mM}$ $\mathrm{Na}_{2} \mathrm{HPO}_{4}$ ). Midguts were transferred to Carson's formalin fixative solution (CARSON et al. 1973) for 24 hours at room temperature. After fixation, 1-mm fragments of the anterior and posterior midgut regions of each midgut were washed in saline solution and stained with DAPI (diamidino-2-phenylindole) for 30 minutes, then washed in distilled water and mounted in a $50 \%$ sucrose solution. In addition, midgut fragments were dehydrated in an ethanol graded series (70-100\%) and embedded in historesin (Leica). Slices $3 \mu \mathrm{m}$ thin were stained with toluidine-blue-borax (1\%) and analyzed under a light microscope.

From the histological sections, six areas per midgut fragment were arbitrarily selected and photographed with a $40 \mathrm{X}$ objective (total area $=0.414 \mathrm{~mm}^{2}$ ). In total, 20 nuclei of digestive and ten nuclei of regenerative cells of the midgut epithelia were measured per area in pupae and adults, respectively. In addition, a total of 640 and 320 nuclei of digestive and regenerative cells were measured in pupae, respectively, whereas 560 and 280 nuclei of digestive and regenerative cells were measured in adult midguts, respectively. Images from DAPI-stained midguts were taken using an Olympus BX-60 epifluorescence microscope (Olympus, Japan), with a UV filter coupled with a Q-Color 3 Olympus digital camera. For all the measurements taken, nuclei were arbitrarily selected, measured and their respective areas determined with the aid of Image-Pro Plus 4.5 software (Media Cybernetics, USA).

The statistical analysis was performed with the SigmaStat 3.2 software (SPSS Inc., Chicago, IL, USA). The analysis of variance (ANOVA) was used to compare the means of nuclei number and area of the four experimental groups, followed by the Newman-Keuls method for normal distribution and by the Kruskal-Wallis test for non-parametric data. In the latter, the difference among the groups was determined by the Dunn's method at a 5\% significance level.

The midgut epithelium of $\mathrm{n}$ and $2 \mathrm{n}$ pupae and adult males of M. quadrifasciata anthidioides comprised mainly columnar digestive cells (Figs 1 and 2). The nests of regenerative cells were located between the digestive cells, in contact with the basal membrane. Externally to the basal membrane, there were two layers of muscle: the inner circular muscle and the outer longitudinal muscle. In addition, adult digestive cells had a well-developed brush border, which was absent in pupae; in addition, adult digestive cells and regenerative cell nests were more visually obvious compared with those in the pupae (Figs 1 and 2). Nevertheless, in both pupae and adults, the digestive cells had larger round-shaped nuclei compared with those of regenerative cells. In addition, the regenerative cells were clustered forming nests of different sizes and containing different numbers of cells in pupae and adults (Figs 3 and 4).

The anterior and posterior midgut regions were studied separately to count and measure the nuclei. However, this previous analysis revealed that there was no significant difference between these two regions in terms of cell number and nuclei area (data not shown). Therefore, data from these two regions were used together in the statistical analysis. In $\mathrm{n}$ and $2 \mathrm{n}$ blackeyed pupae, there were $2076 \pm 0.60$ digestive cells per 0.414 $\mathrm{mm}^{2}$ midgut area, whereas in $\mathrm{n}$ and $2 \mathrm{n}$ adult males, there were $1234 \pm 1.42$ cells/area (Fig. 5). Additionally, digestive cells of $n$ and $2 \mathrm{n}$ adults had the largest mean nuclear area of $\sim 154 \mu \mathrm{m}^{2}$, whereas in $\mathrm{n}$ and $2 \mathrm{n}$ pupae, the mean nuclear area was $\sim 91$ $\mu \mathrm{m}^{2}(\mathrm{p}<0.05)$ (Fig. 6). Irrespective of male ploidy or developmental stage (i.e. pupae or adult), the number of regenerative cells/nest varied between nests from 5 to 23 cells in the midgut epithelium, which was on average $\sim 12$ cells $(P=0.548)$. Also, the nuclear area of regenerative cells was almost the same $(\sim 27$ $\mu \mathrm{m}^{2}$ ) in $\mathrm{n}$ or $2 \mathrm{n}$ pupae and adults (data not shown).

This work represents the first description of the midgut epithelium of $2 \mathrm{n}$ males and the first comparative study of the digestive tract of $\mathrm{n}$ and $2 \mathrm{n}$ pupa and adult males of $M$. quadrifasciata anthidioides. In addition, the whole mounts of the midgut enabled the identification, counting and measurement of the DAPI-stained nuclei of digestive and regenerative cells. Not surprisingly, in the two male groups studied, $\mathrm{n}$ and $2 \mathrm{n}$ midguts had the same general morphology and cell organization. Our analysis showed that digestive and regenerative cells comprise the midgut epithelium of these males and this result is consistent with previous descriptions for workers and queens of M. quadrifasciata anthidioides (Cruz-LANDIM 1985, Neves et al. 2003, Martins et al. 2005, França et al. 2006).

Although the number of digestive cells per midgut area is almost 1.7-times less than in $\mathrm{n}$ and $2 \mathrm{n}$ adult males compared with $\mathrm{n}$ and $2 \mathrm{n}$ pupae; this difference is likely to result from the fact that the digestive cells in pupae are smaller than in adults, and so they are more abundant per midgut area. It was previously shown that the number of regenerative cells per nest decreases during the aging of adult workers of Apis mellifera $\mathrm{L}$. and M. quadrifasciata anthidioides (RAEs et al. 1994, Cruz-LANDIM \& Moraes 2000, França et. al. 2006). This difference based on adult aging seems to be exclusive to adult females, given that the number of regenerative cells is similar in pupae and adult males of M. quadrifasciata anthidioides.

The nuclear area of both $\mathrm{n}$ and $2 \mathrm{n}$ adult males is almost 1.7-fold greater compared with that of their corresponding pupae. This variation in the nuclear area of the digestive cell might be a product of the DNA amplification that results from endopoly- 

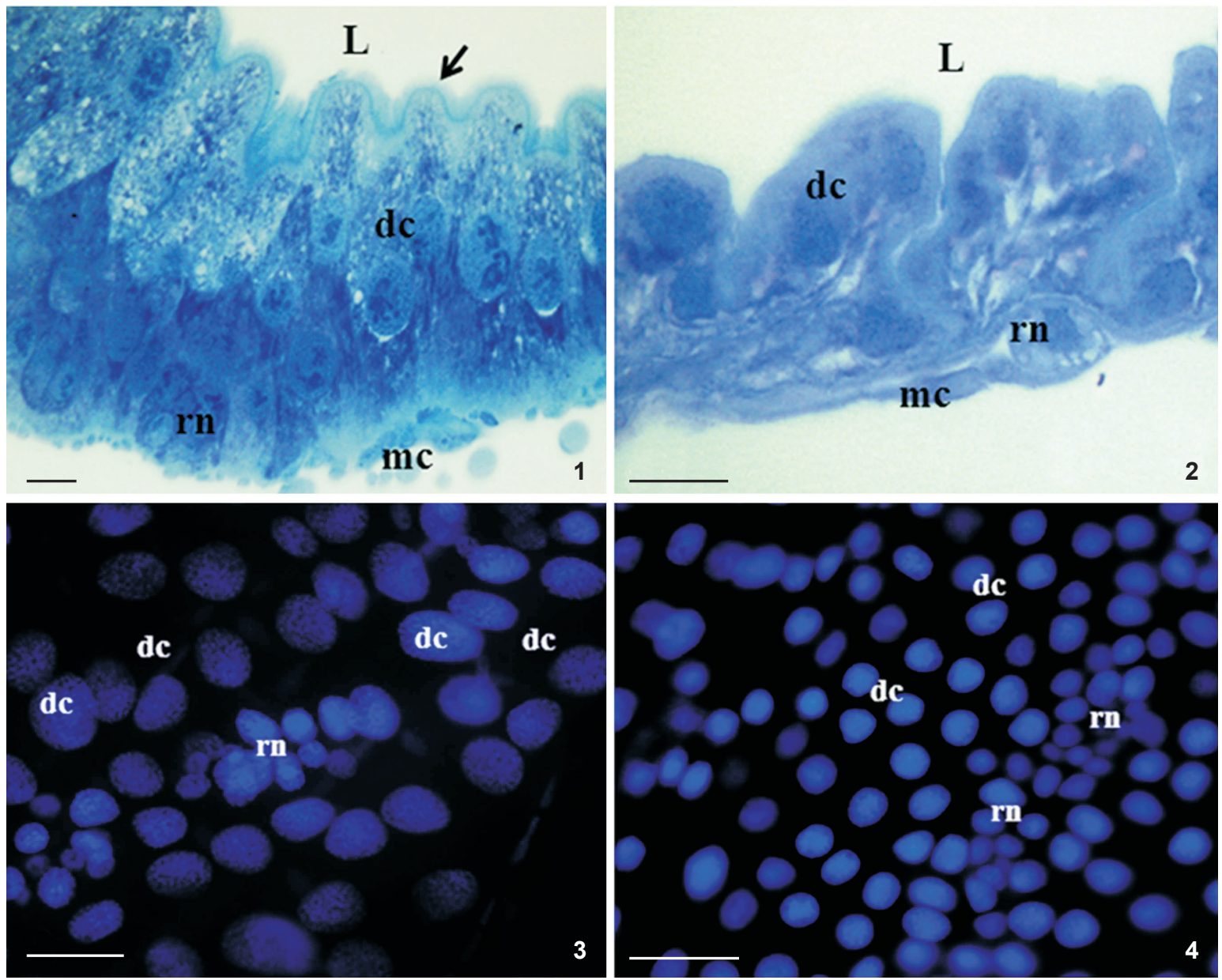

Figures 1-4. Toluidine blue-stained histological sections (1-2) and DAPI-stained whole mounts (3-4) of the midgut epithelium of Melipona quadrifasciata anthidioides males. (1) Cross-section of the midgut showing digestive cells (dc) and a regenerative cell nest ( $r n)$ in the $2 \mathrm{n}$ adult. Key: arrow, striated border; mc, muscle. (2) Longitudinal section of the midgut of $2 \mathrm{n}$ black-eyed pupae. Key: L, lumen; mc, muscle. (3-4) show part of the posterior region of the midgut of $\mathrm{n}$ adult and pupae males, respectively, with the large dc and a rn with small nuclei. Note that the digestive cells have nuclei with sizes that differ according to their location. Scale bar $=20 \mu \mathrm{m}$.

ploidy, polytheny or nuclear fusion during insect development or aging (ButTerworth \& RASCH 1986). This phenomenon might be due to an increase in the synthesis of digestive enzymes, which results from increased food ingestion during insect development (ZuDAiRE et al. 2004), or it might be a consequence of the effects of the juvenile hormone (DirTMan et al. 1989).

Even the original DNA content of $2 \mathrm{n}$ bees is twice that of $\mathrm{n}$ ones, surprisingly, their digestive and regenerative cells have the same nuclear area in these two groups. It appears that this difference in DNA content between $\mathrm{n}$ and $2 \mathrm{n}$ individuals, at least for digestive and regenerative cells, is not significant to be detected by morphometric tools. Furthermore it is reasonable to speculate that the DNA amplification occurs at different rates, so that DNA synthesis is higher in n males compared with 2n males. However, this has yet to be confirmed for $M$. quadrifasciata anthidioides.

The present study demonstrated that the number of digestive cells/area was greater in $\mathrm{n}$ and $2 \mathrm{n}$ pupae compared with the corresponding adults, whereas the nuclear area of the digestive cells was greater in adult males compared with pupae of $M$. quadrifasciata anthidioides. By contrast, the number of regenerative cells/nest and their nuclear area were the same in these two developmental stages. We conclude that the ploidy difference between $\mathrm{n}$ and $2 \mathrm{n}$ male stages does not affect the number of digestive and regenerative cells in the midgut of $M$. quadrifasciata anthidioides.

Here, we have reported on the first comparative study of the midgut of $\mathrm{n}$ and $2 \mathrm{n}$ males of the stingless bee M. quadrifasciata 

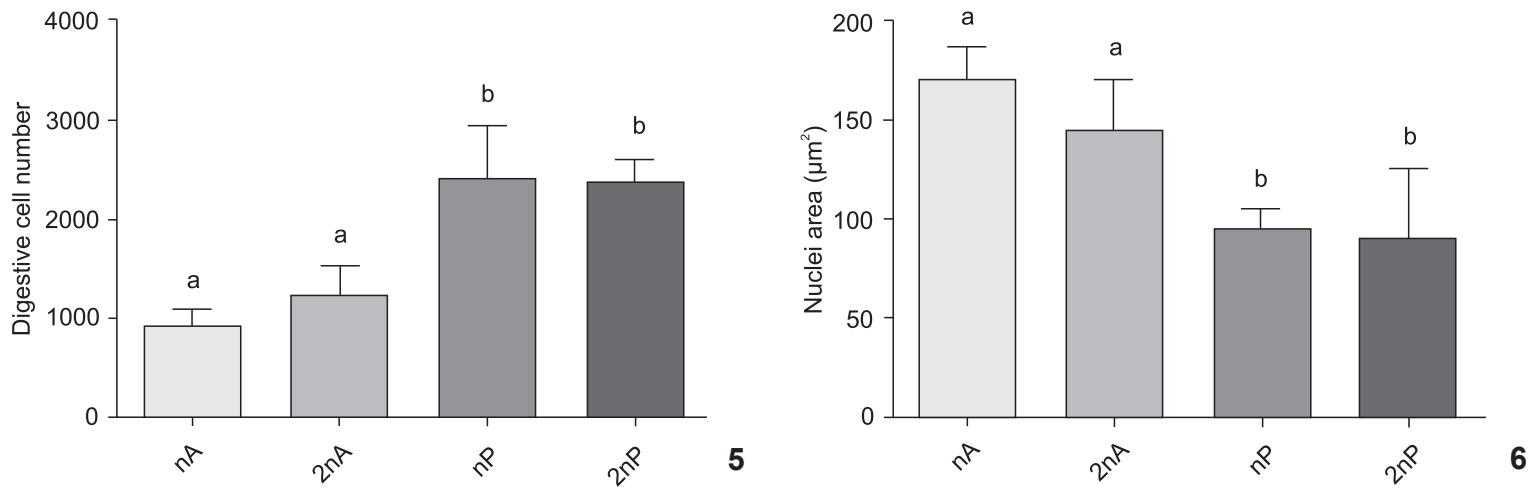

Figures 5-6. Number and nuclear area $\left(\mu \mathrm{m}^{2}\right)$ of digestive cells of haploid (nP) and diploid (2nP) pupae males and haploid (nA) and diploid ( $2 \mathrm{nA})$ adult males of Melipona quadrifasciata anthidioides. Vertical bars denote standard error. Different letters indicate significant differences in: (5) the number of digestive cells per $0.414 \mathrm{~mm}^{2}$ of midgut area; and (6) the nuclear area.

anthidioides, with examination of the number and area of nuclei of digestive and regenerative cells of both pupae and adults. Such a comparative approach could help improve current understanding of the morphological and physiological aspects of the digestive tract of bees.

\section{ACKNOWLEDGEMENTS}

This work was supported by Fundação de Amparo a Pesquisa de Minas Gerais (FAPEMIG) and Coordenação de Aperfeiçoamento de Pessoal de Nível Superior (CAPES).

\section{LITERATURE CITED}

Billingsley, P.F. \& M.J. Lehane. 1996. Structure and ultrastructure of the insect midgut, p. 31-54. In: M.J. Lehane \& P.F. Billingsley (Eds). Biology of the insect midgut. London, Chapman and Hall, 486p.

Butterworth, F.M. \& E.M. Rasch. 1986. Adipose tissue of Drosophila melanogaster: Distribution of nuclear DNA amounts along the anterior-posterior axis in the larval fat body. Journal of Experimental Zoology 239 (1): 77-85.

Camargo, C.A. 1979. Sex determination in bees. XI. Production of diploid males and sex determination in Melipona quadrifasciata. Journal of Apicultural Research 18 (2): 77-84.

Camargo, C.A. 1982. Control of production of Melipona quadrifasciata diploid males by workers bees (Hymenoptera., Apidae), p. 248-249. In: M.D. Breed; C.D. Michener \& H.E. Evans (Eds). The biology of social insects. Boulder, Westview Press 419p.

Carson, F.L.; J.H. Martin \& J.A. Lynn. 1973. Formalin fixation for electron microscopy. A re-evaluation. American Journal of Clinical Pathology 59 (3): 365-373.

Cook, J.M. 1993. Sex determination in the Hymenoptera: a review of models and evidence. Heredity 71: 421-435.
Cruz-Landim, C. 1985. Origin of the peritrophic membrane of the adult Apis mellifera (Hymenoptera: Apidae). Revista Brasileira de Biologia 45 (3): 207-219.

Cruz-LANDim, C. 1999. Ultrastructural features of the regenerative cells of the bees (Hymenoptera, Apidae) midguts. Sociobiology 34 (3): 597-603.

Cruz-Landim, C. \& M.L.S. Mello. 1970. Post-embryonic changes in Melipona quadrifasciata anthidioides Lep. IV. Development of the digestive tract. (1). Boletim de Zoologia e Biologia Marinha 1: 229-263.

Cruz-Landim, C. \& R.L.S.M. Moraes. 2000. Morte celular programada em abelhas como uma forma de redirecionar a morfologia e a fisiologia adaptativa. Rio Claro, Editora e Tipografia Costa, 48p.

Dittmann, F.; P.H. Kogan \& H.H. Hagedorn 1989. Ploidy levels and DNA synthesis in fat Body cells of the adult mosquito, Aedes aegypti: the role of juvenile hormone. Archives of biochemistry and physiology 12 (3): 133-143.

Duchateau, M.J. \& J. Mariën. 1995. Sexual biology of haploid and diploid males in the bumble bee Bombus terrestris. Insectes Sociaux 42 (3): 255-266.

Fernandes, K.M.; V.A. AraúJo; J.E. Serrão; G.F. Martins; L.A.O. Campos \& C.A. Neves. 2010. Quantitative analyses of the digestive and regenerative cells of the midgut of Melipona quadrifasciata anthidioides (Hymenoptera; Apidae). Sociobiology 56 (2): 490-505.

França, A.A.P.; S.N. Dessaune; J.E. Serrão \& C.A. Neves. 2006. The regenerative cell in the midgut of Melipona quadrifasciata anthidioides (Hymenoptera, Apidae, Meliponini): a comparative study of workers and queens. Brazilian Journal of Morphological Science 23: 401-404.

Martins, G.F.; C.A. Neves; L.A.O. Campos \& J.E. Serrão. 2005. The regenerative cells during the metamorphosis in the midgut of bees. Micron 37 (2): 161-168.

Michener, C.D. 1974. The social behaviour of the bees. A comparative study. Cambridge, Belknap Press, $404 \mathrm{p}$. 
Neves, C.A.; J.E. Serrão \& L.B. Gitirana. 2003. Ultrastructural study of the metamorphosis in the midgut of Melipona quadrifasciata anthidioides (Apidae, Meliponini) worker. Sociobiology 41 (2): 443-459.

Raes, H.; M. Verbeke; W. Meulemans \& W. Coster. 1994. Organisation and ultrastructure of the regenerative crypts in the midgut of the adult worker honeybee (L. Apis mellifera). Tissue and Cell 26 (2): 231-238.

Rothenbuhler, W.C; J.M. Kulincevic \& W.E. Kerr. 1968. Bee genetics. Annual Review of Genetics 2: 413-438.

Serrão, J.E. \& C. Cruz-Landim. 1996. Ultrastructure of digestive cells in stingless bees of various ages (Hymenoptera, Apidae, Meliponinae). Cytobios 88: 161-171.
SerRÃo, J.E. \& C. Cruz-LANDim. 2000. Ultrastructure of the midgut epithelium of Meliponinae larvae with different developmental stages and diets. Journal of Apicultural Research 39 (1-2): 9-17.

Terra, W.R. 1990. Evolution of digestive systems of insects. Annual Review of Entomology 35: 181-200.

Woyke, J. \& SкоWronek, W. 1974. Spermatogenesis in diploid drones of the honey bee. Journal of Apicultural Research 13 (3): 183-190.

Zudaire, E.; S.J. Simpson; I.L. Illa \& M. Montuenga. 2004. Dietary influences over proliferating cell nuclear antigen expression in the locust midgut. Journal of Experimental Biology 207 (13): 2255-2265.

Submitted: 29.I.2012; Accepted: 08.VIII.2012.

Editorial responsibility: Carolina Arruda Freire 